TITLE:

\title{
Excitation of Spin-Flip States of Light Nuclei in Inelastic Scattering of Alpha Particles( Abstract_要旨 )
}

AUTHOR(S):

Nakamura, Hitoshi

\section{CITATION:}

Nakamura, Hitoshi. Excitation of Spin-Flip States of Light Nuclei in Inelastic Scattering of Alpha Particles. 京都大学, 1967, 理学博士

ISSUE DATE:

1967-05-23

URL:

http://hdl.handle.net/2433/212258

RIGHT: 


\section{【 $19 】$}

\section{氏 名}

学位の種 類 学位記番号 学位授与の日付 学位授与の要件 研究科 · 専攻 学位論文題目

論文調查委員

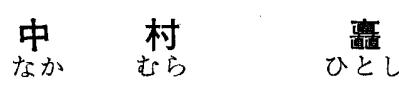

理 学 博 士

理 博 第 121 号

昭 和 42 年 5 月 23 日

学 位規則第 5 条第 1 項該当

理学研究科物理学専攻

Excitation of Spin-Flip States of Light Nuclei in Inelastic Scattering of Alpha Particles

（アルファ粒子の非弾性散乱による軽い核のスピンフリップ状態の励起） (主 查) 教授柳父琢治教授小林稔教授武藤二郎

\section{論文内容 $の$ 要旨}

本論文は， $\mathrm{B}^{11} ， \mathrm{C}^{12}, \mathrm{Mg}^{24}$ および $\mathrm{S}_{\mathrm{i}}{ }^{28}$ の 4 種の原子核の励起状態を, 京都大学サイクロトロンで得られ るエネルギー28. $5 \mathrm{MeV}$ のアルファ粒子の非弾性散乱の方法を用いて研究し，特にスピンフリップ状態之 称せられる励起状態に着目して，その発現機構その他に考察を加えた結果を記載したものである。

スピンフリップ状態というのは，原子核中の 1 個の核子がスピンを反転したことによって生じたと考え られる励起状態を言う。一般には，スピンが反転すると共に，軌道角運動量す変化するので純粋なスピン 反転を観測するのは困難であるが，申請者は他種の実験より確定されている，C12 核のスピンフリップ状 態を基準にとり，他の三種の原子核について，軌道角運動量が変化せず核子のスピンのみが反転したと見 られる励起状態を探索している。

本研究を行なうに当たって，特に実験上留意した点は，適切な原子核を選択するととの他に，前方 $5^{\circ} ま$ での小角度での非弾性散乱を検出すること，エネルギー分解能を向上せしめて，高い励起状態まで分離測 定するととの 3 点であったが，従来は成功例に至しく，今回の研究はすぐれた実験技術を示している。

実験結果の第 1 は， $C^{12}$ 原子核に関して約 7 種の励起状態を観測し，てのうちスピンフリップ状態であ るととが確認されている, 励起エネルギー12.8MeVの状態に対応する非弾性散乱アルファ粒子は, 重心 系で約 $25^{\circ}$ の所にピークを有し，後方には何等ピークが現われない極めてユニークな角度依存性を示すと とが判明したととである。申請者はとの特異な角度依存性がスピンフリップ状態の励起と本質的な関連が あるとの推量の屯とに実験を行ない, $\mathrm{B}^{11}$ の $8.6 \mathrm{MeV}$ 励起状態, $\mathrm{Mg}^{24}$ の $10.4 \mathrm{MeV}$ 励起状態, $\mathrm{S}_{\mathrm{i}}{ }^{28}$ の $8.9 \mathrm{MeV}$ 励起状態の扔のおのに対応する散乱アルファ粒子が，全く同様の特異な角度依存性を有するととを見出し た。これは徒来得られていない新しい知識である。次に申請者は,アルファ粒子の角度依存性, 断面積の 絶対值, イソスピン保存則, 励起エネルギーの大きさ, 等を考慮して, てれらの励起状態のスピンパリテ イがスピンフリップ状態の持つ量子数で与えられることを示した後, この状態が励起される機構に関して 次の考察进行なっている。即ち，スピンフリップ状態は，アンナチュラルパリティ状態（異常偶奇性状 
態）の中の一種であるから，その機構は，少なくと屯異常偶奇性を説明し得る屯のでなくてはならない。 従って考え得る機構は，複合核過程を経由するか，2段階フォノン励起か, 電磁気相互作用による励起 か，核内核子のスピン反転によるかである。更にスピンフリップ状態の励起を説明し得る機構は，このう ちのいずれかに制限される。まず角度依存性より，複合核過程ではあり得ない。又 2 段階フォノン励起で あれば，実験結果よりもゆるやかな角度低存性を示す筈である。更に，10 MeV 程度の高い励起状態は， 基底状態と結合の少ない，単一核子励起状態であるのが通例で，フォノン励起は生じ難い。更に，断面積 の絶対值は，電磁気相互作用で予想されるよりはるかに大きい等の理由によって，前 3 者の機構は排除さ れる。従って，スピン反転による励起が唯一の機構である。この場合，アルファ粒子はスピンを有しない ので，スピンを反転させる作用は，入射アルファ粒子と，核子との間のスピン軌道相互作用が核子スピン を反転させるものと考えられる。申請者は，この推定を確認するため，核子の波動函数を選定した上で， スピン軌道相互作用を取り入れた，散乱断面積を，平面波インパルス近似によって計算し，実験結果によ く適合する結果を得ている。

参考諭文その 1 は, アルファ粒子の非弾性散乱の方法を用いた, $0^{16}, \mathrm{~N}_{\mathrm{e}}{ }^{20}, \mathrm{Mg}^{24}$ および $\mathrm{S}_{\mathrm{i}}{ }^{28}$ の異常偶奇性の

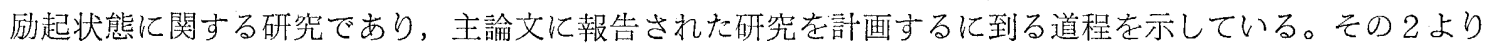
その 5 までは, いずれもアルファ粒子の非弾性散乱による軽い原子核の励起状態の研究であり, 複合核過 程, 直接過程による原子核の励起が詳細に研究されている。参考諭文その 6 は, 重陽子中の陽子, 中性子の おのおのと,アルファ粒子との相互作用を研究したあので, 主諭文の内容をさらに基礎づけたものである。

\section{論文審查の結果の要旨}

アルファ粒子の原子核による非弾性散乱現象は, 1959年頃より原子核の励起状態の研究に有用であると とが認められて来たが，その理由は，アルファ粒子が原子核表面で吸収され易いために，原子核表面の状 態, 即ち表面振動の様子を忠実に反映すると考えられた点にあった。申請者は, 約 5 年前より, 一貫して

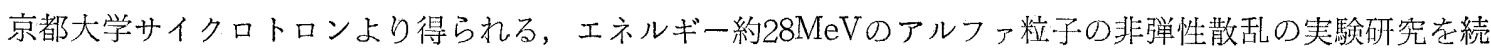
け，特に軽い核に集中してその励起状態の研究を行なって来た。主論文以前の研究は，参考論文その 1 乃 至 5 に報告されている如く，質量数が奇数の原子核， $\mathrm{B}^{11}, \mathrm{C}^{13}, \mathrm{Al}^{27}$ 扝よび $\mathrm{P}^{31}$ について，又偶一偶核であ

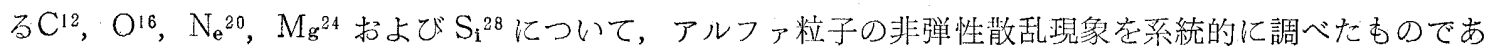
る。この時に問題としたのは，従来中重核以上の重い核について認められた法則性，即ち，アルファ粒子 の非弾性散乱においては，基底状態との結合の強い集団運動の励起状態が生じ易いとされている法則性 が，軽い核に扔いても成立するかどうかとう点であった。研究の結果は，乙の法則性は成立する場合が 多いが，軽い核に特有の例外的な場合も見受けられるというととである。その1は，奇数核に拉けるコア 一励起現象の存在であり，その 2 は，偶一偶核に扔ける，アンナチュラルパリティ状態（異常偶奇性状 態）の励起される現象であった。この例外的励起現象は，アルファ粒子が原子核表面で吸収され易いとい う従来の常識からは，解粎に困難を来たすすのであった。即ち，從来の常識よりすれば，アルファ粒子が 原子核に，一回の衝突でエネルギーを与える限り，フォノン励起がが圧倒的に生洅る筈であるからであ る。申請者はとの 2 種の例外的な現象は，アルファ粒子が，核内核子と直接に作用するためであるうる推 
定し，その推定を確かめる研究を計画，実行した。その結果が主論文に報告されている事項である，スピ ンフリップ状態の励起の研究である。申請者の考えは，第 1 段階として，既にスピンフリップ状態である ことが，陽子の非弾性散乱その他の垁験より確認されている， $\mathrm{C}^{12} の 12.7 \mathrm{MeV}\left(1^{+}\right)$状態が， $\alpha$ 粒子によっ てあ同様に励起されるかどうかを確かめ，その結果を未知の原子核に及ぼすととであった。結果は，3種 の内容を含んでいるが，第 1 に， $\mathrm{C}^{12} の 12.7 \mathrm{MeV}\left(1^{+}\right)$状態は，アルファ粒子によってあ励起可能であり， 非弾性散乱を受けたアルファ粒子は，普通の集団運動を励起した場合に見られる如き，廻折現象を示さ ず，特殊の角度依存性を示すとと，第 2 亿, 奇数核である $\mathrm{B}^{11}$ にいても，全く同様の角度依存性を示す 㽶起状態があり，とのレベルがスピンフリップ状態の可能性があるとされている事実に矛盾しないとと， 第 3 に，偶一偶核 $\mathrm{Mg}^{24}$ および $\mathrm{S}_{\mathrm{i}}{ }^{28}$ ， 彷来知られていないスピンフリップ状態が存在することの 3 点であ

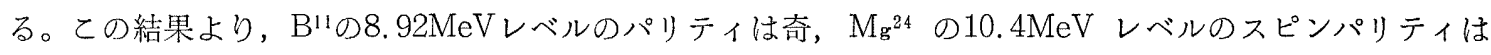
$1^{+}, \mathrm{S}_{\mathrm{i}}{ }^{28}$ の8.9MeVレベルのスピンパリティも同様に $1^{+}$と評定された。この成果は，そ机自体で価值を有 するが，一面，如何なる機構を以って，スピンフリップ状態が励起されるかについて問題を提供する。ス ピンフリップ状態とは，基底状態とスピン量子数 1 の差を有し，パリティを等しくする状態であるから， その励起は，2フォノン励起によるか，複合核過程を経るか，電磁気的な相互作用によるか，核内の核子 1 個のスピンが反転するによるかのいずれかである。申請者はこの 4 種の励起機構を検討して, 前 3 者は 実験結果を説明ずるには不充分であり，原子核内の核子のスピン反転によるものであることを示した上 で，核子のスピン反転を生ずるのは，アルファ精子と核子との間のスピン一軌道相互作用によるものと考 え，平面波インパルス近似のもとに理論的解析を行ない，実駼結果をほぼ説明し得ることを示した。

以上の成果は, 従来の常識を破る新鮮味を有し，アルファ粒子と原子核との間の相互作用に新しい見解 をもたらした点で原子核物理学上の進歩に笴与するとてろ少なからざるものがある。参考論文の内容を併 せ考えると, 申請者の研究は，一歩一歩着害に積みあげられたあのと言うべきであり，本論文はさらに将 来の発展を期待させる内容を有している。

よって本論文は理学博士の学位論文として価值があるるのと認める。 